Chirurgia (2017) 112: 208-216

No. 3, May - June

Copyright@ Celsius

http://dx.doi.org/10.21614/chirurgia.112.3.208

\title{
The European Policy for Liver Allocation in Patients Affected by Hepatocellular Carcinoma
}

\author{
Stefano Di Sandro', Fabio Ferla', Andrea Lauterio', lacopo Mangoni', Riccardo De Carlis ${ }^{1,2}$, Vincenzo Buscemi ${ }^{1,2}$, \\ and Luciano De Carlis ${ }^{1,3}$
}

'Department of General Surgery and Transplantation, Niguarda Ca' Granda Hospital, Milan, Italy

${ }^{2}$ Department of Surgical Sciences, Universityof Pavia, Italy

${ }^{3}$ International Center for Digestive Health, Department of Medicine and Surgery, University of Milan-Bicocca, Milan, Italy

Corresponding author:

Stefano Di Sandro, MD PhD

Department of General Surgery

and Transplantation

Ospedale Niguarda Ca' Granda, Milan

Piazza Ospedale Maggiore, 3

E-mail: stefano.disandro@ospedaleniguarda.it

\section{Rezumat}

Politica europeană de alocare a organelor pentru transplant hepatic la pacientii cu carcinom hepatocelular

Scopul principal al sistemului de alocare este garantarea accesului în mod egal la resursa limitată de grefe hepatice pentru toate categoriile de pacienți aflați pe lista de aşteptare, asigurând un echilibru între principiile etice de echitate, utilitate, beneficiu, nevoie şi justețe. Scopul acestui articol este de a analiza politica alocării grefelor hepatice în anumite organizatii, concentrându-ne pe carcinomul hepatocelular (HCC). Zona europeană luată în considerare pentru această analiză include şase zone / țări, care utilizează aceeaşi politică de alocare / schimb al grefelor hepatice. În urma acestei definiții, cele şase zone identificate sunt: Centro Nazionale Trapianti (CNT) în Italia; Eurotransplant (Germania, Olanda, Belgia, Luxemburg, Austria, Ungaria, Slovenia şi Croația); Organizacion Nacional de Transplantes (ONT) în Spania; Etablissement français des Greffes (EfG) în Franța; NHS Blood \& Transplant (NHSBT) în Regatul Unit al Marii Britanii şi Irlanda; Scandiatransplant (Suedia, Norvegia, FInalnda, Danemarca şi Islanda); Politica Națională din România. Fiecare zonă identificată ca rețea pentru partajarea de organe în Europa adoptă un sistem de alocare cu o politică orientată înspre centru sau înspre pacient. Prioritizarea la nivel mondial a pacienților cu HCC aflați pe listele de aşteptare pentru transplant hepatic de la donatori decedați se face respectând două principii: urgența şi utilitatea. Mesajul principal al prezentei lucrări este atragerea atenției asupra absenței unei politici comune pentru alocarea organelor în țările 
europene. În ciuda acestui fapt, există o rată de supraviețuire pe termen lung a pacienților aflați pe listele de aşteptare pentru transplant datorită rezultatelor HCC, acceptabilă în Europa şi comparabilă cu supraviețiirea pe termen lung raportată în registrul UNOS.

Cuvinte cheie: carcinom hepatocelular, transplant hepatic, politică de alocare

\begin{abstract}
The main goal of allocation system is to guarantee an equal access to the limited resource of liver grafts for every class of patients on the waiting list, balancing between the ethical principles of equity, utility, benefit, need, and fairness. The aim of this review was to analyze liver allocation policies among these organizations, focusing on HCC. The European area considered for this analysis included 6 macro-areas or countries, which are congregated from the same policy of liver sharing and allocation. By this definition, the 6 areas identified are: Centro Nazionale Trapianti (CNT) in Italy; Eurotransplant (Germany, the Netherlands, Belgium, Luxembourg, Austria, Hungary, Slovenia, and Croatia); Organizacion Nacional de Transplantes (ONT) in Spain; Etablissement français des Greffes (EfG) in France; NHS Blood \& Transplant (NHSBT) in the United Kingdom and Ireland; Scandiatransplant (Sweden, Norway, Finland, Denmark, and Iceland); Romanian National Policy. Each identified area, as network for organ sharing in Europe, adopts a basic allocation system that consider a policy center oriented or patient oriented. Priorization of patients affected by HCC in the waiting list for deceased donors liver transplant worldwide is dominated by 2 main principles: urgency and utility. The main message of this review is the absence of a common organs allocation policy over the Eurpean countries. Despite that, long-term survival of the community of patients listed for transplant due to HCC results, however, highly acceptable in Europe and comparable to the long-term survial reported in the UNOS register.
\end{abstract}

Key words: hepatocellular carcinoma, liver transplantation, allocation policy

\section{Introduction}

The first liver transplantation (LT) for hepatocellular carcinoma (HCC) was reported in early 1967 (1). Unfortunately, the cases performed in that first experience developed early tumor recurrence and death in a few months after transplant. Because of that, HCC has been widely recognized as a contraindication for LT (2) up to the mid-90s. On 1996, Mazzaferro V. and co-workers published their pioneering results showing that the post-transplant survival of patients with early HCC was similar to that of noncancer patients (3). Since then, LT has become the standard of care for early hepatocellular carcinoma in cirrhotic patients around the world. The "Milan criteria" are universally accepted as the benchmark for patient selection for LT. When it comes to liver transplantation for hepatocellular carcinoma, we must distinguish two aspects:

- Indication for transplant and selection criteria adopted (Milan criteria, the San Francisco criteria, up-to-seven, etc.);

- Priority of patients in respect to the other patients with hepatocellular and patients listed for non-tumor indications.

A recent analysis from the ELTR (european liver transplant register) reports a progressive increase of LT performed for HCC in the last decade (4). This trend is confirmed in the UNOS database (5) in the United States. The increasing number of patients with hepatocellular carcinoma in the transplant waiting lists has created a strong competition between 
tumor and non-tumor candidates for transplant. The imbalance between the growing number of candidates for LT and limited donor pool makes it crucial to determine the allocation and prioritization policies that ensure fair and equal access.

By this way, authors suggested many allocation schemes over the years aimed to ensure equal access to LT. All these schemas found on principled of fairness, utility, and convenience. In 2002 UNOS adopted the Model for End-stage Liver Disease (MELD) scoring system for liver allocation, in order to reduce list mortality and consequently drop-out. MELD score was originally developed to estimate the 3-month mortality risk for cirrhotic patients undergoing trans-jugular intrahepatic porto-systemic shunt placement; it is based on three objective measures: total bilirubin level, serum creatinine level, and INR international normalized ratio (INR). Since the introduction of MELD, ELTR data have shown a steady decline in waiting list mortality as well as a shortening in median time to transplant without any negative impact on post-transplant outcome. The main drawback of MELD score is its inability to quantify the drop-out risk for clinical conditions reather than ESLD.

Most HCC patients present with normal creatinine/bilirubin/INR levels, and thus with a low MELD score (for such patients disease severity is not reflected by functional impairment expressed by MELD), and the drop-out risk is determined by disease progression. In order to overcome this structural defect, UNOS has recognized HCC (and other diseases whose severity is not reflected by pure MELD score, i.e. primary biliary cirrhosis) as a "MELD exception", attributing extra-poits and thus prioritizing $\mathrm{HCC}$ patient to reduce drop-out risk due to disease progression. Originally patients with stage I disease (single tumor < $2 \mathrm{~cm}$ ) received 24 points, and those with stage II disease (single tumor $\leq 5 \mathrm{~cm}$ or two to three tumors, all $\leq 3 \mathrm{~cm})$ received 29 points $(30 \%$ 3 -month mortality risk). Additional points were given every 3 months, provided candidates remained within the Milan criteria. This policy led to a substantial increase in the proportion of recipients receiving $\mathrm{LT}$ for $\mathrm{HCC}$ at the expense of candidates with other diagnoses, leading to a subsequent reduction in exception points awarded for HCC April 2003 (20 MELD points for stage I and 24 points for stage II). Later on, it became apparent that stage I candidates did not have a significant 3-month mortality, so that stage I candidates received no exception, and stage II candidates were awarded with 22 MELD points. While USA has developed a central organ (UNOS/OPTN) who coordinates liver procurement and allocation at a national level, such system is still lacking in the European Europe: there are different organ exchange organizations for different countries and geographical areas. The aim of this review was to analyze liver allocation policies among these organizations, focusing on HCC.

\section{Materials and Methods}

This study was a comprensive review of the literature including all the articles, in English lenguage, published on indexed journals since 2000 until now. We have analyzed articles focalized on the criteria of livers allocation over the European centers involved in liver transplantation programs. Twenty-seven articles were excluded from the analysis because of an old policy of allocation, which was subsequently reviewed and modified until the current adopted policy.

The European area considered for this analysis included 6 macroareas or countries, which are congregated from the same policy of liver sharing and allocation. By this definition, the 6 areas identified are:

- Centro Nazionale Trapianti (CNT) in Italy;

- Eurotransplant (Germany, the Netherlands, Belgium, Luxembourg, Austria, Hungary, Slovenia, and Croatia);

- Organizacion Nacional de Transplantes (ONT) in Spain;

- Agence Nationale de la Biomedicine in France;

- NHS Blood \& Transplant (NHSBT) in the United Kingdom and Ireland; 
- Scandiatransplant (Sweden, Norway, Finland, Denmark, and Iceland);

- National Agency for Transplantation.

The allocation policy of the livers from deceased donors worldwide is dominated by 2 main principles: urgency and utility. The principle of Urgency is based on the severity of patient disease. Patients waiting for liver transplantation are more than available organs, thus every patient candidate for liver transplantation is exposed to a risk of death or a risk of dropout from the waiting list because of complications of their disease while waiting for the transplant. Basing on this assumption, the aim of the urgency policy of priority is incentrated on the decrease of patient dropout risk. By this way, in the urgency-based models of priorization the aim of liver allocations is "seekest first". Patients at higher risk of dropout should be transplanted first. This model does not take into account the transplantation outcome and the impact of alternative treatments on the survival of transplantable patients. Generally, centers who adopt an urgency-based policy for patients candidate due to HCC consider some variables such as MELD score, time from listing, size and numbers of nodules as a tool to give points to the patients in view to achieve a scale of priority balanced with the risk of patient dropout (6-8). Leading models based on the urgency policy for HCC are the HCC-MELD, de MELD, new de-MELD) (6-9). Advantages of this policy are the lowest drop-out risk for the patients and the re-arranging risk basing on the tumor response to the pre-transplant locoregional treatments. However, these urgencybased models do not consider at all patient outcome after transplantation, thus sometimes the seekest patient does not represent the best patient for the transplant because of the higher mortality risk after transplantation than patients at earlier stage of the liver disease.

The Utility-based model, contrarialy, considers as better candidate for transplantation the patient who may gain the highest number of life-years by transplantation. Therefore, considering the best utility to assign the liver at that patient, this model may calculate a real survival benefit obtained from the transplant trough the formula of the number of years gained by the transplant minus the number of years offered by alternative treatments. Advantages of this model is the consideration of both pre- and post-transplant outcomes, including the results of alterative treatments, in view to achieve the best survival benefit by the transplant avoiding to offer transplant for patients who may have a scarce gain of survival compared to the results obtained from alternative treatments (10-12). Limits of this model for liver allocaction in patients affected by HCC may be essentially related to the outliers. The ideal survival benefit should take into account all the factors that may impair survival of patients before and after transplantation, not only variables related to the underlying disease, but also variables related to the patients baseline characteristcs and lifestyle. Therefore, considering the high numbers of variables that may escape from the consideration of the survival benefit, this model may results less effective to be applied on the entire cohort of patients waiting for the transplant. Moreover, the leading studies reporting this model was constructed on the basis of 5-year survival rather than on the 10-20 year horizon; this may limit the real appreciation of the benefit of the transplant in compare to the alternative treatments. Lastly, each area identified as network for organ sharing in Europe adopts a basic allocation system that consider a policy center oriented or patient oriented. Center oriented policy means that the network center of coordination assingn the deceased donor to a center, basing of geographic and/or some rotational criteria, and subsequently the center associate that donor to a proper recipient basing on a center owen priority list. On the other hand, the patient oriented policy means that, regardless the geographic distribution or centers rotation, livers are allocated in a common shared list basing on the patient absolute priority. The UNOS system may be considered the maximum example of a patient oriented policy. 


\section{Results}

On the basis of the above mentioned principles (of urgency and utility) the main European allocation and prioritization policies result to be as follows:

- Graft allocation is coordinated by CNT (Centro Nazionale Trapianti) and it is center-oriented with prioritization based on patient MELD scores in the Italian Area. Indications for HCC transplant are made according to the "Milan criteria" or the "up to seven", but no-central policy is shared for allocating liver grafts to tumoral recipients yet, therefore organs are allocated within each center's waiting-list independently. The Bologna group reported its internal model for HCC prioritization (13): it is based on tumor stage and time on the waiting list (14). Interestingly the Bologna team preferentially allocate elderly grafts on HCC low-meld recipients (13). The Padua group has recently developed an allocating system capable of ranking priority in both $\mathrm{HCC}$ and non-HCC recipients: the "HCC-MELD". This method is based on liver function and AFP levels; its end-point is the survival benefit (15). A task force is currently working to implement a nationwide policy on liver allocation to $\mathrm{HCC}$ recipients.

- The Eurotrasplant area covers the majority of central Europe and includes Germany, the Netherlands, Belgium, Luxembourg, Austria, Hungary, Slovenia, and Croatia. Organ allocation is patient oriented in Germany, Belgium, the Netherlands, Luxembourg and center oriented in Austria, Hungary, Slovenia and Croatia.

Patients are prioritized according to their MELD score. HCC patients are listed according to Milan Criteria (a single nodule $<5 \mathrm{~cm}$ or up to three nodule $<3 \mathrm{~cm}$ ). HCC represents a MELD exception and prioritization in HCC cases is calculated as follows: MELD score equivalent to a $15 \%$ probability of death within 3 -months at the time of listing (the only exception to this rule is the Netherlands with a starting MELD equivalent to a $10 \%$ probability of death within 3-months), plus 10\% MELD equivalent bonus every three months for patients who don't drop out for disease progression out to the Milan criteria (16).

The ELAS (Eurotranplant Liver Allocation System) manual well defines the Eurotransplant allocation method.

Graft retrieval and allocation are coordinated by the Organizacion Nacional de Transplantes (ONT) in the Spain Area. Liver allocation is center-oriented. As for Eurotransplant area, HCC liver transplant indications are made according to the "Milan criteria". Prioritization is made upon MELD score and HCC represents a MELD exception. The rules to prioritize HCC recipients are reviewed every year by professionals from every transplant centers and proposed changes are approved by the regional health authorities.

The rule changes are generally based on the analysis of: liver transplant activity, donor characteristics, waiting list time, probability of being transplanted for different recipient characteristics, mortality while waiting, and emergency and re-transplantation rates per hospital.

A recent survey (17) pointed out that many transplant teams considers critical parameters HCC stage and waiting list time. Prioritization is therefore based on MELD score plus extrapoints for HCC recipients. National guidelines recommend to prioritize HCC patients assigning 15 to 19 extra points at the time of listing, with the periodical gain of additional points with increasing wiaiting time (18).

Graft allocation is coordinated by the "Etablissement français des Greffes" and it is patient-oriented in the France Area.

Prioritization is made according to The French Liver Allocation System (FLAS) since 2007. The FLAS system takes into account the cirrhosis severity (by the means of MELD score) as well as other conditions not related to MELD (eg, HCC and the need for re-transplantation). For every liver transplant indication specific formulas have been developed to compute a prioritization score. This formulas 
are based on a national retrospective analysis by the Agency of Biomedicine.

$\mathrm{HECH}$ patients are listed according to the "Milan Criteria" (a single nodule $<5 \mathrm{~cm}$ or up to three nodule $<3 \mathrm{~cm}$ ). The maximum points an $\mathrm{HECH}$ recipient can get depends on the MELD-score and HECH stage: for example a T1 - 6 MELD patient can obtain up to 360 points, a T2 - 6 MELD patient can obtain up to 450 points.

These points are progressively acquired by patients on the waiting list, and the progression rate varies with the $\mathrm{HECH}$ stage. For patients with T1 HECH who have a low and stable score and do not progress on the waiting list in the first months, the slope increases until 12 to 18 months; this ideally leads to access to a graft within a year. In contrast, patients with T2 HECH must obtain access faster. No initial delay is considered, and points are continuously given from the time of listing until the point maximum is obtained; this theoretically leads to access to a liver graft after 6 months. Again, patients with high MELD scores and HECH obtain access to transplantation more rapidly than patients with low MELD scores. (19)

The National Health Service Blood \& Transplant (NHSBT) coordinates graft procurement and allocation through the National Organ Retrieval Service since 2011 in United Kingdom and Ireland Area. The NHSBT allocation is center-oriented with prioritization based on patient UKELD scores (a modified MELD including $\mathrm{Na}$ as a variable) (20).

$\mathrm{HECH}$ patients are listed according to the "Milan Criteria" (a single nodule $<5 \mathrm{~cm}$ or up to three nodule $<3 \mathrm{~cm}$ ) and no strict rules are applied to rank their priority. When a graft is allocated to a transplant center the recipient is chosen by the transplant surgeons on the basis of many factors (including quality and size of the donated liver, blood group compatibility, health condition of different suitable recipients, and logistics of pressure on intensive care unit beds and on staff). National guidelines currently do not specify which patient to select when a liver suitable for more than one recipient is offered and the outcomes of this policy in terms of waiting list drop out are unknown (21).
The Scandiatransplant Area covers the Nordic Countries and includes Sweden, Norway, Finland, Denmark, and Iceland. In this area the organ donation rate is very favorable therefore there's a very short waiting list time and no strict prioritization policy is needed. The allocation system is centeroriented and each transplant center has the right to transplant livers procured from a defined geographical area. Just in a few cases transplant centers use MELD-score locally to allocate grafts to patients in the greatest need (22).

HCC patients are listed according to the "Milan Criteria" (a single nodule $<5 \mathrm{~cm}$ or up to three nodule $<3 \mathrm{~cm}$ ).

Clinical parameters (e.g., MELD-score, the Child-Turcotte-Pugh scores, medical urgency, recipient size, recipient age) are generally used in conjunction with non-clinical parameters (e.g., waiting time) to select patients to be transplanted when a graft is allocated to a transplant center.

In the Romanian Area the allocation system managed by the National Agency for Transplantation is patient-oriented. For prioritization to transplantation both MELD score and the HCC corrected MELD score is adopted (23). Patients whos meet the Milan criteria, the allocation policy is the same as for the other listed patients and MELD score is corrected by additional points. Concerning patients outside the Milan Criteria and with low Meld score may receive marginal livers, which are not consudered suitable to be allocated in a non-cancer and very sick patient. For patients with HCC the following criteria for listing and transplantation were used: presence of strictly intrahepatic tumors, without macrovascular invasion regardless of the Child or MELD score, any BCLC stage. For patients with HCC the MELD score was not assigned to be 20 or 24 as proposed by UNOS, but calculated as usual.

\section{Discussion and Conclusions}

Liver allocation policies are very heterogeneous in Europe: most of the European 
Transplant organizations are center-oriented and a myriad of factors influence the decision on the actual recipient of a graft. Differently from the patient-oriented systems, each center establishes its own criteria of prioritization of patients in the waiting list, this is why organized data are missing on how the organs are assigned to actual recipients.

In spite of this very complex scenario favorable long term survival and intention-totreat survival are reported on many European patient cohorts. It is possible that such different liver allocation criteria allow flexibility and permit adaption to very different local condition: HCC and ESDL prevalence, organ donation rate, availability of economic resources are examples of highly variable conditions in different European areas.

Although survival results are favorable in transplanted patients, clear data on patients not listed for liver transplant are not available.

Because of the above mentioned reasons we cannot assess with certainty the ability of the European Transplant organizations to satisfy the liver transplant needs, to guarantee uniform access to the available resources and to guarantee the principles of equity and transparency (3-18).

In the last decade many European centers applied the urgency-based patient-oriented UNOS-method on a local scale. This method is in part utility-based, as only patients inside the Milan criteria (i.e. with better a priori prognosis) are listed. HCC patients receive a modified MELD score that reflects the timebased dropout risk for their given oncologic stage ( $\mathrm{T} 1$ or $\mathrm{T} 2$ ) and additional points are awarded independently to the response to intermediate treatments. This system creates a greater likelihood of transplant patients with HCC compared to patients with nonneoplastic diseases so determining a disadvantage for the latter (12-19).

In contrast to the urgency-based method a survival benefit approach is supposed to be more uniform and predictable by promoting an ideal balance between the principles of urgency and utility. This is why many authors have proposed a prioritizing system that takes into account variables having a strong impact on the individual patient risk of dropout and post-transplant outcome, such as alpha-fetoprotein (AFP) and MELD score itself. Among these authors Vitale et al have proposed a scoring method (the HCC-MELD) to prioritize both $\mathrm{HCC}$ and non-HCC recipients. The goal of the HCC-MELD is to maximize the survival benefit by predicting the years of life that a patient earns with the transplant compared to alternative treatments to transplant. This model does not neglect the principle of utility as it also poses a minimum threshold of posttransplant survival of $50 \%$ at 5 years, excluding therefore the patients who do not have that expected prognosis. The performance of this model is awaiting validation (15).

Mazzaferro V. may have been able to square the circle in the arena of transplant indication and graft allocation in patients with HCC with a recently published model (25).

The proposed model applies to BCLC A and B patients (vascular invasion, extrahepatic metastases, or other contraindications are considered exclusion criteria for tranplant) and aims to evaluate the dropout risk and post-transplant outcomes related to the biology and response to alternative treatments of the tumor. Patients with high MELD would be prioritized according to liver function.

Transplantable patients (TT) with lowMELD cirrhosis are therefore classified in 8 groups: the lowest priority is assigned to patients that previously underwent radical treatment of $\mathrm{HCC}$ and have no viable tumor into the liver at the time of listing (TTOc) or last follow-up. The highest priority, on the other hand, goes to patients with recurrent HCC after initial down-staging or after resection performed less than 2 years before the recurrence diagnosis (TTDR). In between of these two stages, the author considered 6 more classes of priority from the lowest to the highest: patients with no viable tumor after effective loco-regional chemo or radio embolization (TTOL), patients with single active $\mathrm{HCC}<2 \mathrm{~cm}$ (TT1), patients down- 
staged effectively with a not transplantable HCC at the time of tumor diagnosis (TTNT), patients with $\mathrm{HCC}>\mathrm{T} 1$ or recurrent $\mathrm{HCC}$ after resection performed longer than 2 years before tumor recurrence diagnosis (TTFR); patients not amenable to alternative treatments of HCC because of ascites, but tumor compatible with transplant criteria (TTUT); patients with not complete response to the bridging loco-regional treatment and viable tumor into the liver (TTPR) $(25,26)$.

The response to the bridging loco-regional treatment is a tool to re-assess priority for the candidate patients to LT in our experience too (27): patients at the same tumor stage in term of size and number of nodules may have different outcomes based on tumor biology and the response to treatment.

The model proposed by Mazzaferro appears to be capable of contemplating the different scenarios of HCC presentation and seems to be a useful tool in setting the HCC priorities. By assigning higher priority to those at higher risk of progression after alternative treatment, it makes the best use of the transplant resource (population utility) while still prioritizing the sickest. This model is awaiting to be validated, while further work is needed to balance urgency/utility with the goal to achieve the best benefit in patient survival.

In conclusion, the allocation of livers for patients waiting for transplantation in Europe changes areas-by-areas and sometimes centersby-centers. Despite that, long-term survival of the community of patients listed for transplant due to HCC results acceptable and comparable to the long-term survival reported in the UNOS register. Exploration of alternative allocation policies should continue to improve equity, transparency and effectiveness of the liver transplantation. Future policies should modulate recipient priorities taking into account two parameters: the alfa-fetoprotein variation in transplant candidates and tumor response to the loco-regional treatments performed while patients are waiting for the liver. The general scenario is changing at a fast pace because of the impact of Hepatitis C cure worldwide. This will force physicians to re-assess the global allocation policies and indications for liver transplantations in the very close future.

\section{References}

1. Ringe B, Pichlmayr R, Wittekind C, Tusch G. Surgical treatment of hepatocellular carcinoma: experience with liver resection and transplantation in 198 patients. World J Surg. 1991;15(2):270-85.

2. Ryder SD. Guidelines for the diagnosis and treatment of hepatocellular carcinoma (HCC) in adults. Gut. 2003;52 Suppl 3:iii1-8.

3. Mazzaferro V, Regalia E, Doci R, Andreola S, Pulvirenti A, Bozzetti F, et al. Livertransplantation for the treatment of small hepatocellular carcinomas in patients with cirrhosis. N Engl J Med. 1996;334(11): 693-9.

4. Adam R, Karam V, Delvart V, O'Grady J, Mirza D, Klempnauer J, et al. Evolution of indications and results of liver transplantation in Europe. A report from the European Liver Transplant Registry (ELTR). J Hepatol. 2012;57(3):675-88. doi: 10.1016/j.jhep.2012. 04.015. Epub 2012 May 16.

5. Ioannou GN, Perkins JD, Carithers Jr RL. Liver transplantation for hepatocellular carcinoma: impact of the MELD allocation system and predictors of survival. Gastroenterology. 2008;134(5):134251. doi: 10.1053/i.gastro.2008.02.013. Epub 2008 Feb 13.

6. Toso C, Majno P, Berney T, Morel P, Mentha G, Combescure C. Validation of a dropout assessment model of candidates with/without hepatocellular carcinoma on a common liver transplant waiting list. Transpl Int. 2014;27(7):686-95. doi: 10.1111/tri.12323. Epub 2014 Apr 25.

7. Merani S, Majno P, Kneteman NM, Berney T, Morel P, Mentha G, et al. The impact of waiting list alpha-fetoprotein changes on the outcome of liver transplant for hepatocellular carcinoma. J Hepatol. 2011;55(4): 814-9. doi: 10.1016/j.jhep.2010.12.040. Epub 2011 Feb 18.

8. Toso C, Mentha G, Majno P. Liver transplantation for hepatocellular carcinoma: five steps to prevent recurrence. Am J Transplant. 2011;11(10):2031-5. doi: 10.1111/j.1600-6143.2011.03689.x. Epub 2011 Aug 10.

9. Toso C, Mazzaferro V, Bruix J, Freeman R, Mentha G, Majno P. Toward a better liver graft allocation that accounts for candidates with and without hepatocellular carcinoma. Am J Transplant. 2014;14(10): 2221-7. doi: 10.1111/ait.12923. Epub 2014 Sep 12.

10. Merion RM, Schaubel DE, Dykstra DM, Freeman RB, Port FK, Wolfe RA. The survival benefit of liver transplantation. Am J Transplant. 2005;5(2):307-13.

11. Schaubel DE, Sima CS, Goodrich NP, Feng S, Merion RM. The survival benefit of deceased donor liver transplantation as a function of candidate disease severity and donor quality. Am J Transplant. 2008; 8(2):419-25. doi: 10.1111/j.1600-6143.2007.02086.x. Epub 2008 Jan 7.

12. Cillo U, Vitale A, Volk ML, Frigo AC, Grigoletto F, Brolese A, et al. The survival benefit of liver transplantation in hepatocellular carcinoma patients. Dig Liver Dis. 2010;42(9):642-9. doi: 10.1016/ j.dld.2010.02.010. Epub 2010 Apr 8.

13. Ravaioli M, Grazi GL, Ercolani G, Cescon M, Del Gaudio M, Zanello M, et al. Liver allocation for hepatocellular carcinoma: a European Center policy in the pre-MELD era. Transplantation. 2006;81(4): 525-30.

14. Ravaioli M, Grazi GL, Ballardini G, Cavrini G, Ercolani G, Cescon M, et al. Liver transplantation with the Meld system: a prospective study from a single European center. Am J Transplant. 2006;6(7): 1572-7.

15. Vitale A, Volk ML, De Feo TM, Burra P, Frigo AC, Ramirez Morales R, et al. A method for establishing allocation equity among patients with and without hepatocellular carcinoma on a common liver transplant waiting list. J Hepatol. 2014;60(2):290-7. doi: 10.1016/ j.jhep.2013.10. 010. Epub 2013 Oct 23.

16. Eurotransplant manual - chap 5. Available at www.eurotransoplant.org

17. Ramos Rubio E, Ortiz de Urbina J, Santoyo Santoyo J, Varo Pérez E; 17 grupos de trasplante hepático españoles. Degree of uniformity in 
the treatment of hepatocellular carcinoma in the Spanish teams of liver transplantation. Med Clin (Barc). 2013:141(9):406-10. doi: 10.1016/j.medcli.2013.03.009. Epub 2013 May 22. Spanish

18. Pardo F, Pons JA, Briceño J; en nombre de la Sociedad Española de Trasplante Hepático. V Consensus Meeting of the Spanish Society for Liver Transplant on high-risk recipients, immunosupression scenarios and management of hepatocarcinoma on the transplant waiting list. Cir Esp. 2015;93(10):619-37. doi: 10.1016/ j.ciresp.2015.04.007. Epub 2015 Jul 15. English, Spanish

19. Francoz C, Belghiti J, Castaing D, Chazouillères 0 , Duclos-Vallée $\mathrm{JC}$, Duvoux C, et al. Model for end-stage liver disease exceptions in the context of the French model for end-stage liver disease scorebased liver allocation system. Liver Transpl. 2011;17(10):1137-51.

20. Barber KM, Pioli S, Blackwell JE, et al. Development of a UK score or patients with end-stage liver disease. Hepatology 2007;46: $510 \mathrm{~A}$.

21. Menon KV, Hakeem AR, Heaton ND. Review article: liver transplantation for hepatocellular carcinoma - a critical appraisal of the current worldwide listing criteria. Aliment Pharmacol Ther. 2014;40(8):893-902. doi: 10.1111/apt.12922. Epub 2014 Aug 26.

22. Fosby B, Melum E, Bjøro K, Bennet W, Rasmussen A, Andersen IM, et al. Liver transplantation in the Nordic countries - An intention to treat and post-transplant analysis from The Nordic Liver Transplant Registry 1982-2013. Scand J Gastroenterol. 2015;50(6):797-808. doi: 10.3109/00365521.2015.1036359.

23. lacob S, Gheorghe L, lacob R, Gheorghe C, Hrehoret D, Popescu I. MELD exceptions and new predictive score of death on long waiting lists for liver transplantation. Chirurgia (Bucur). 2009;104(3):267-73.

24. Cillo U, Burra P, Mazzaferro V, Belli L, Pinna AD, Spada M, et al. A Multistep, Consensus-Based Approach to Organ Allocation in Liver Transplantation: Toward a "Blended Principle Model". Am J Transplant. 2015;15(10):2552-61. doi: 10.1111/ajt.13408. Epub 2015 Aug 14.

25. Mazzaferro V. Squaring the circle of selection and allocation in liver transplantation for HCC: An adaptive approach. Hepatology. 2016;63(5):1707-17. doi: 10.1002/hep.28420. Epub 2016 Feb 26.

26. De Giorgio M, Vezzoli S, Cohen E, Armellini E, Lucà MG, Verga G, et al. Prediction of progression-free survival in patients presenting with hepatocellular carcinoma within the Milan criteria. Liver Transpl. 2010;16(4):503-12. doi: 10.1002/lt.22039.

27. De Carlis L, Di Sandro S, Giacomoni A, Slim A, Lauterio A, Mangoni I, et al. Beyond the Milan criteria: what risks for patients with hepatocellular carcinoma progression before liver transplantation? J Clin Gastroenterol. 2012;46(1):78-86. doi: 10.1097/MCG. 0b013e31822b36f6. 